\title{
R. J. Harvey-Gibson, C.B.E., D.L., M.A., I).Sc.
}

Robert John Harvey-Gibson, Emeritus Professor of Botany in the University of Liverpool, died on 3rd June 1929, in his sixty-ninth year. He was elected to the Royal Society of Edinburgh in 1885; he resigned later, but was re-elected in 1914. Having been resident in England during his long tenure of the Chair in Liverpool, he never held office in the Society, though he contributed from time to time to its publications. He left his mark on the University of Liverpool by the design and establishment of the Hartley Botanical Institute, one of the finest in the country.

He was a "son of the manse." His father, the Rev. R. Gibson, was an adherent of the Scottish Episcopal Church. The son was born on 2nd November 1860, and was educated at the Grammar. School, Aberdeen, and at the Universities of Aberdeen, Edinburgh, and Strassburg, under Trail, Dickson, and De Bary. His first appointment was as demonstrator in Zoology and Physiology in Edinburgh, and his earliest papers were on zoological subjects. His official life in Liverpool opened as demonstrator in Biology in the University College, where he became later Lecturer in Botany; and on its receiving University status he was the first Professor of the subject in Liverpool. His tenure of the chair extended from 1894 to his resignation in 1921. During that long period he proved himself an excellent teacher : he also acted as examiner in Bristol, Aberdeen, Glasgow, Dublin, the Pharmaceutical Society of Great Britain, and also for the University of New Zealand. After his retirement he lived successively at Grasmere, and Leamington, and finally at Glasgow, where he died somewhat suddenly. He married in 1887 Eda, daughter of Rev. J. Lawrie, and grand-daughter of Adam Black, M.P., Lord Provost of Edinburgh. He left one daughter. He held the degrees of M.A. and D.Sc., and having done valuable service in Liverpool during the war he was given the C.B.E., 1919, and appointed D.L., and J.P. of the County Palatine of Lancaster.

Harvey-Gibson's earlier work was mainly zoological, and eight Memoirs are entered in the Royal Society Catalogue up to 1890. His botanical publications opened in 1887, the most notable being an elaborate series giving an anatomical analysis of the genus Selaginella (Ann. of Bot., viii, x, $x i, x v i)$. These memoirs are marked by the beauty of the illustrations, for in draughtsmanship his powers were exceptional. In later years he devoted time to diagrams for the lecture-room, in the rendering of which the 
originals gained in effect, while they lost nothing in accuracy. His anatomical interest extended latterly to the more primitive Dicotyledons, and two Memoirs produced jointly with pupils have been published in our Transactions (vol. li, p. 589; vol. lii, p. 501).

From time to time Harvey-Gibson issued floristic Reports on Marine Algæ for the Liverpool Marine Biological Committee; also lists for the Oban district, and for the Sudanese Red Sea. The last was constructed jointly with Miss Margery Knight, whose beautifully illustrated Memoirs on the Ectocarpaceæ have been published in the Transactions of the Society. These carry to the highest point of theoretical interest the work on Algæ started by Harvey-Gibson in Liverpool.

In his later years he turned to literary rather than observational work. He translated for the Oxford Press Jost's Lectures in Plant Physiology (1907); and he produced Outlines of the History of Botany (1919); The Master Thinkers (Nelson, 1829), and other volumes.

The scientific work of Harvey-Gibson was analytical rather than constructive. This feature comes out particularly in the series of Memoirs on Selaginella, which take their permanent place as evidence of faithful observation, recorded with an artistic touch that is not often equalled and has rarely been excelled.

F. O. B. 